\title{
Effects of Cadmium on Laminaria saccharina in Culture
}

\author{
J. W. Markham ${ }^{1}$, B. P. Kremer ${ }^{2}$ and K. R. Sperling ${ }^{3}$ \\ ${ }^{1}$ Biologische Anstalt Helgoland, D-2192 Helgoland, Federal Republic of Germany \\ ${ }^{2}$ Botanisches Institut der Universität, Gyrhofstr. 15, D-5000 Köln 41, Federal Republic of Germany \\ ${ }^{3}$ Biologische Anstalt Helgoland, Wüstland 2, D-2000 Hamburg 55, Federal Republic of Germany
}

\begin{abstract}
Cadmium effects were tested on 50-d-old laboratory-grown sporophytes of the kelp Laminaria saccharina under continuous-flow laboratory conditions. In standard 6-d experiments the rapid rate of growth of the plants $(30 \%$ length increase $\mathrm{d}^{-1}$ in controls) provided a suitable parameter for the measurement of cadmium effects. Over a 6 -d period a concentration of 4.5 $\mathrm{ppm} \mathrm{Cd}$ was lethal. There is evidence that a lower concentration would be lethal over a longer period of exposure. In the range of 0.2 to $4.5 \mathrm{ppm} \mathrm{Cd}$ the reduction in growth rate with increasing Cd concentration was nearly linear. The growth rate diminished to $50 \%$ of the controls at approximately $2.15 \mathrm{ppm} \mathrm{Cd}$. When plants exposed to cadmium for $6 \mathrm{~d}$ were measured after a further $8 \mathrm{~d}$ in unpolluted seawater, the concentration causing growth-rate reduction to $50 \%$ of the controls was $0.86 \mathrm{ppm} \mathrm{Cd}$. Long-term after effects are more serious than is immediately evident and exposure time is more important than concentration. Cadmium uptake begins almost immediately and is apparently unregulated, indicating potentially very high tissue concentrations. Over $100 \mathrm{ng}$ $\mathrm{Cd} \mathrm{mg}$ dry $\mathrm{wt}^{-1}$ was accumulated by plants in $6 \mathrm{~d}$ from a $0.78 \mathrm{ppm}$ Cd solution. Saturation was not reached. Relatively more cadmium is taken up from lower ambient concentrations. Slower-growing plants and slower-growing regions of the thallus (stipe/holdfast; distal blade region) take up relatively more cadmium. At concentrations over $2.3 \mathrm{ppm}$ Cd the blades show a sharply delimited distal loss of pigment. Cadmium inhibits photosynthesis, as well as dark carbon assimilation. The degree of inhibition depends on time and concentration. In distal plant regions the photosynthetic potential is more sensitive to cadmium. The reduction in photosynthesis in the most actively growing region with increasing cadmium concentration follows a curve very similar to that for the reduction in growth. The decrease in growth and photosynthetic potential caused by cadmium is not correlated with pigment loss or cadmium accumulation.
\end{abstract}

\section{INTRODUCTION}

Since cadmium was found to be the cause of the endemic 'itai itai' disease in the Toyama District of Japan (Kobayashi, 1970) this metal has attracted increasing attention as an environmental pollutant. It is found only in minute traces in unpolluted environments. Its normal concentration in ocean waters seems to lie below $0.1 \mu \mathrm{g} \mathrm{l}^{-1}$ (Goldberg, 1965; Riley and Taylor, 1968; Bryan, 1971; Preston, 1973), whereas polluted coastal and inshore waters can, in certain cases, contain several $\mu \mathrm{g} \mathrm{l}^{-1}$. In general, Cd concentrations of the German Bight (North Sea) range between 0.02 and $0.2 \mu \mathrm{g} \mathrm{l}^{-1}$ (Schmidt, 1976; Sperling, unpublished).

It is well known that low concentrations of $\mathrm{Cd}$ can cause serious chronic effects (Friberg et al., 1974). Although several studies have been conducted recently regarding the influence of $\mathrm{Cd}$ on marine organisms, relatively few have dealt with marine plants and the majority of these were conducted on unicellular algae. Species of the kelp Laminaria have been tested more frequently with a variety of other pollutants. Pieces cut from fronds of $L$. digitata were examined for the effects of zinc (Bryan, 1969). L. saccharina was tested in seawater containing undefined pollutants (Burrows, 1971; Burrows and Pybus, 1971) and detergents (Pybus, 1973); L. hyperborea was tested with a variety of detergents, herbicides, insecticides, $\mathrm{Zn}, \mathrm{Cu}, \mathrm{Hg}$ (Hopkin and Kain, 1971, 1978) and $\mathrm{Cd}$ (Hopkin and Kain, 1978). In these studies, growth measurements were conducted using zoospores, gametophytes, and early sporophyte stages, whereas respiration, when tested, was measured in discs cut from adult, field-collected plants. These Laminaria studies, and analyses of the metal content of brown algae growing in polluted areas, especially species of Fucus (Bryan and Hummerstone, 1973; Fuge and James, 1973, 1974; Morris and Bale, 1975; Seeliger and Edwards, 1977) have established that uptake of heavy metals by brown algae is not regulated, reflects the concentration in the ambient seawater, and results in 
very high concentration factors, although the concentration factors are greater where the environmental concentration is lower.

Laminaria saccharina is ubiquitous in temperate northem hemisphere coastal waters and has a rapid growth rate which is very sensitive to culture conditions and can be measured by increase in length. Most previous tests of heavy metals on multicellular marine algae, including the above-noted tests on Laminaria, have been conducted in standing culture, where the growth rate of the algae may be less than optimal, and the concentration of the metal being tested declines over the course of the experiment due to uptake by the algae. The development of automatic flow-through culture systems for producing and testing uniform, unialgal cultures of $L$. saccharina has made it possible to examine the effects of $\mathrm{Cd}$ under controlled conditions of rapid growth and constant pollutant concentration.

\section{MATERIAL AND METHODS}

\section{Plant Material}

Sporophytes of Laminaria saccharina (L.) Lamour. were initiated from stock cultures of gametophytes and grown in the laboratory in unialgal culture on polyethylene rods in an automatic flow-through culture system as described previously (Markham et al., 1979). After $50 \mathrm{~d}$ growth (pretreatment) in enriched seawater (Provasoli, 1968) at $12{ }^{\circ} \mathrm{C}$ under white fluorescent light (Osram $65 \mathrm{~W} / 19$; 2000 lux), the sporophytes were cut back to $20 \mathrm{~mm}$ blade length and two $1.5 \mathrm{~mm}$ holes were punched in each blade at 10 and $15 \mathrm{~mm}$ from the transition zone, respectively. The first hole was for measurements of growth, as previous experiments had shown that the first $10 \mathrm{~mm}$ in small plants like these increased in length by a factor of 2.5 to 3.0 in $5 \mathrm{~d}$, whereas the next $5 \mathrm{~mm}$ only increased by a factor of 1.2 to 1.3. The second hole was punched to provide an indication of possible distal loss of tissue. After measurement of the plants, the specific growth rate $1 \%$ increase $\mathrm{d}^{-1}$ ) was calculated using the formula:

$$
S G R=\frac{100\left[\log _{e}\left(L_{2} / L_{1}\right)\right]}{t}
$$

where $L_{1}=$ initial length (= stipe/blade transition to first punched hole), $L_{2}=$ length on Day $t(=$ stipe/ blade transition to first punched hole on Day $t$ )

\section{Cadmium Treatment}

In the treatment, the prepared plants, each growing attached to its individual polyethylene rod, were tested in a continuous-flow system (Markham et al., 1979). In this system, filtered seawater containing the desired concentration of $\mathrm{Cd}$ (added as $\mathrm{CdCl}_{2}$ ) was pumped continuously by a multichannel peristaltic pump from 20-l glass bottles through polyethylene tubing to test culture vessels (2 l capacity; $22 \mathrm{~cm}$ diameter, $9 \mathrm{~cm}$ high). All test cultures were maintained at $12^{\circ} \mathrm{C}, 16: 8$ light: dark, fluorescent light at 5000 lux (previously determined to be saturating for growth of plants of this age). Before running tests with new concentrations, the desired concentrations of $\mathrm{Cd}$ were pumped once through the system to 'condition' the glassware and minimize possible later adsorption of Cd. Prior to addition of the plants, the test culture vessels were filled again with test solutions from the reservoir bottles by rapid pumping and then allowed to stand overnight. After addition of the plants, the solution was pumped continuously into the vessels at a rate of $2 \mathrm{ml} \mathrm{min}^{-1}$ for a period of $6 \mathrm{~d}$. The solution in the test vessels was stirred continuously by magnetic stirrer. The stirrer was separated from the culture vessel by a l-mm air space and a $5-\mathrm{mm}$ thick sheet of Plexiglas, which prevented overheating of the culture solution by the stirrer. The concentration of $\mathrm{Cd}$ in the water showed essentially no change over $6 \mathrm{~d}$ at any concentration, indicating that the flow rate was sufficient to maintain the concentration despite uptake by the plants.

Due to the rapid rate of growth of control plants, tests longer than $6 \mathrm{~d}$ resulted in overcrowding of the control vessel. One control and 5 test concentrations of $\mathrm{Cd}$ were used in most experiments, with 10-15 plants per test concentration. Cd was added in concentrations of $0.07,0.46,0.97,4.37$ and $8.4 \mathrm{ppm}^{\mathrm{Cd}^{++}}$in initial experiments to determine the lethal concentration. Later experiments were restricted to a lower range

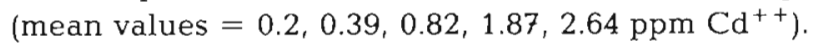

\section{Cadmium Determination}

Water samples were taken from each culture vessel after 2 and again after $6 \mathrm{~d}$ of each experiment and analyzed for Cd content by atomic absorption spectrometry (AAS) as described by Sperling (1977). At the end of the experiment the plants were removed from the culture vessels with glass forceps and the distance from the transition zone to the first punched hole was measured on each plant.

In order to determine the amount of Cd taken up by the plants, one or two entire plants from each concentration were passed rapidly (20 s) through a dehydration series from distilled water to $100 \%$ methanol, dried at $85^{\circ} \mathrm{C}$ for $20-21 \mathrm{~h}$, weighed for dry weight and then analyzed by flameless AAS for Cd content as described by Sperling et al. (1977). 
In one experiment, samples were taken after $6 \mathrm{~d}$ from 5 regions of the plant (holdfast/stipe, transition zone, $10 \mathrm{~mm}$ above transition zone, mid-blade, distal end) and analyzed separately for $\mathrm{Cd}$ content to determine relative uptake rates by different parts of the plant. Uptake rates were determined for whole plants by removing entire plants for $\mathrm{Cd}$ analysis after $1 \mathrm{~h}$ and 1 , 3,5 and $6 \mathrm{~d}$ in $0.86 \mathrm{ppm} \mathrm{Cd}$.

To test recovery from exposure to $\mathrm{Cd}$, plants were grown in sublethal concentrations of 0.38 and $0.86 \mathrm{ppm}$ Cd. After 1, 2, 3, 5 and $6 \mathrm{~d}, 2$ plants were removed from each concentration to uncontaminated seawater in new vessels, where they were allowed to grow further in flow-through conditions until $14 \mathrm{~d}$ after the beginning of the experiment. At this time all plants were measured.

\section{${ }^{14} \mathrm{C}$ Assimilation}

To examine possible effects of $\mathrm{Cd}$ on primary metabolism (cf. Overnell, 1976), Laminaria sporophytes (50 d old) were treated for 24 and $96 \mathrm{~h}$ in Cd-polluted media ranging from 0.16 to $1.5 \mathrm{ppm} \mathrm{Cd}$ and then allowed to assimilate ${ }^{14} \mathrm{C}$ from $\mathrm{H}^{14} \mathrm{CO}_{3}{ }^{-}$for $30 \mathrm{~min}$ both in the light and in the dark. The incubation medium contained the same amount of $\mathrm{Cd}$ as the culture medium plus $10 \mu \mathrm{Ci} \mathrm{NaH}^{14} \mathrm{CO}_{3}(10 \mathrm{ml})^{-1}$. All experiments were conducted with 3 replicates. Further details on the incubation procedure have already been described earlier (Kremer, 1978). After the incubation the plants were briefly rinsed in tap water, cut into stipe, growing zone and distal part of the blade, and separately deep frozen in liquid $\mathrm{N}_{2}$. Assimilation rate calculations were based on (a) the total alkalinity of the seawater medium and (b) the amounts of radiocarbon incorporated in the appropriate conditions. Radioactivity was determined by counting aliquots of ethanolic extracts of the freeze-dried algal material in a scintillation spectrometer. For further analytical details see Kremer (1978).

\section{RESULTS}

\section{Growth of Plants}

Preliminary experiments over the concentration range of 0.07 to $8.40 \mathrm{ppm}$ Cd established that all plants in concentrations of $4.5 \mathrm{ppm}$ or greater were killed in the standard 6-d test. Subsequent experiments concentrated on the sublethal range of 0.2 to $2.6 \mathrm{ppm}$.

In the pretreatment culture system, the plants attained lengths of 50 to $70 \mathrm{~mm}$ in $50 \mathrm{~d}$ (approx. $13 \%$ to $16 \%$ increase $\mathrm{d}^{-1}$ ). In the treatment system, where there were fewer plants per dish and a higher light intensity, the control plants grew 35 to $40 \mathrm{~mm}$ (as measured to the first hole) in $6 \mathrm{~d}$ ( $28 \%$ to $30 \%$ increase $\mathrm{d}^{-1}$; Fig. 1 , conc. ' $\mathrm{O}$ '; Fig. 2, '1') after having been cut back to 20 $\mathrm{mm}$ at the start of the experiment. While the proximal $10 \mathrm{~mm}$ of the blade increased by a factor of 4.5 to 5.0 , the distal $10 \mathrm{~mm}$ only increased by a factor of 1.5 to 2.0 . Thus measurement from the transition zone to the first hole gave an easy measure of growth in the most rapidly growing region and accounted for most of the growth. This rapid growth rate provided a sensitive parameter for measuring the effects of Cd. With plants of this age, no distal loss of tissue occurred.

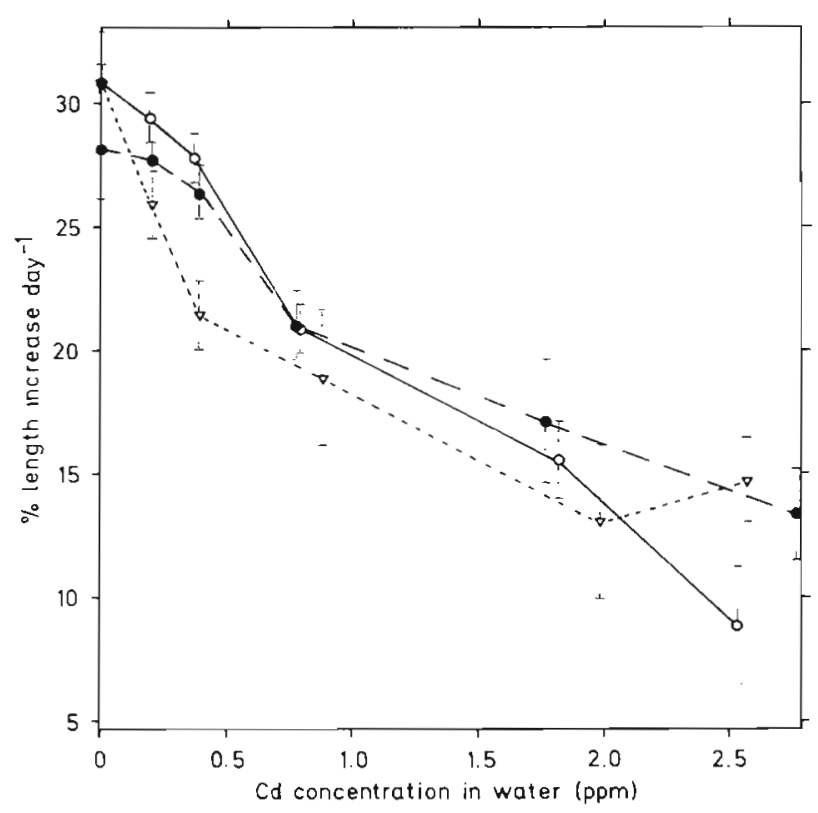

Fig. 1. Laminaria saccharina. Percentage length increase $d^{-1}$ of the original lowermost $10 \mathrm{~mm}$ of plants, measured after $6 \mathrm{~d}$ in various $\mathrm{Cd}$ concentrations (ppm). Vertical bars indicate standard deviations ( 3 experiments)

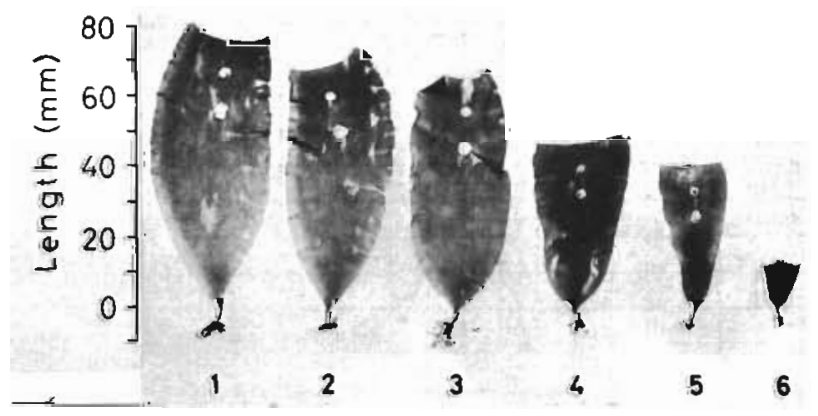

Fig. 2. Laminaria saccharina. Young plants after $6 \mathrm{~d}$ in various Cd concentrations (ppm). All plants (50 d old) were cut back to $20 \mathrm{~mm}$ blade length and had holes punched at 10 and 15 $\mathrm{mm}$ from the transition zone at the start of the experiment. Cd concentrations employed: $1=0.0 \mathrm{ppm}$ (control); $2=0.19$ $\mathrm{ppm}_{;} 3=0.38 \mathrm{ppm} ; 4=0.8 \mathrm{ppm} ; 5=1.83 \mathrm{ppm} ; 6=2.78$ ppm 
Linear regression analysis of the data for the 3 experiments presented in Figure $1(\mathrm{~N}=18$, correlation coefficient $=-0.93$, significant at the 0.01 level) yields a growth rate $50 \%$ of the control rate at a calculated concentration of $2.15 \mathrm{ppm} \mathrm{Cd}$. At concentrations of

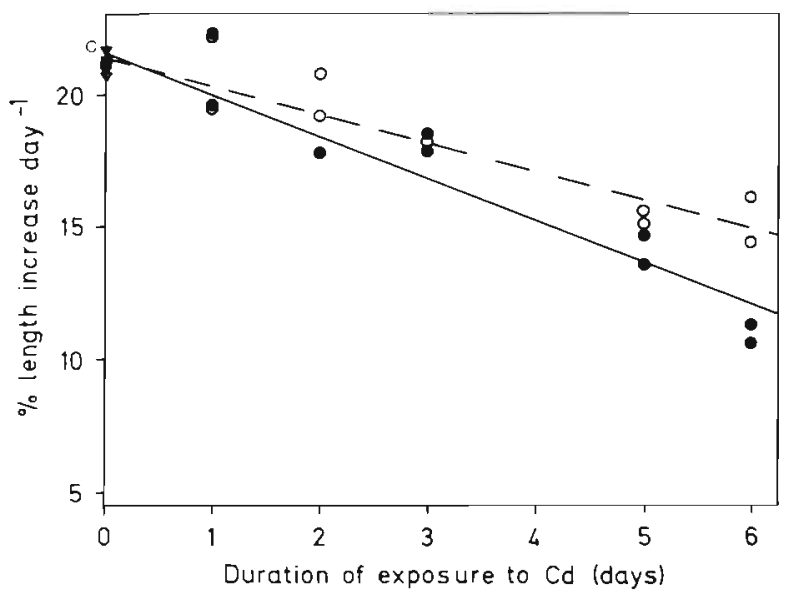

Fig. 3. Laminaria saccharina. Percentage length increase $\mathrm{d}^{-1}$ of the original lowermost $10 \mathrm{~mm}$ of plants after various durations (d) of exposure to $\mathrm{Cd}$, followed by culture in Cd-free water, for $2 \mathrm{Cd}$ concentrations. All plants were measured after $14 \mathrm{~d}$ from the beginning of the experiment. Lines: linear regressions, significant at the 0.01 level $(\mathrm{N}=16$, including control plants). $C(\nabla)=$ control; $O=0.38$ ppm Cd (broken line) $\bullet=0.06 \mathrm{ppm} \mathrm{Cd}$ (solid line)

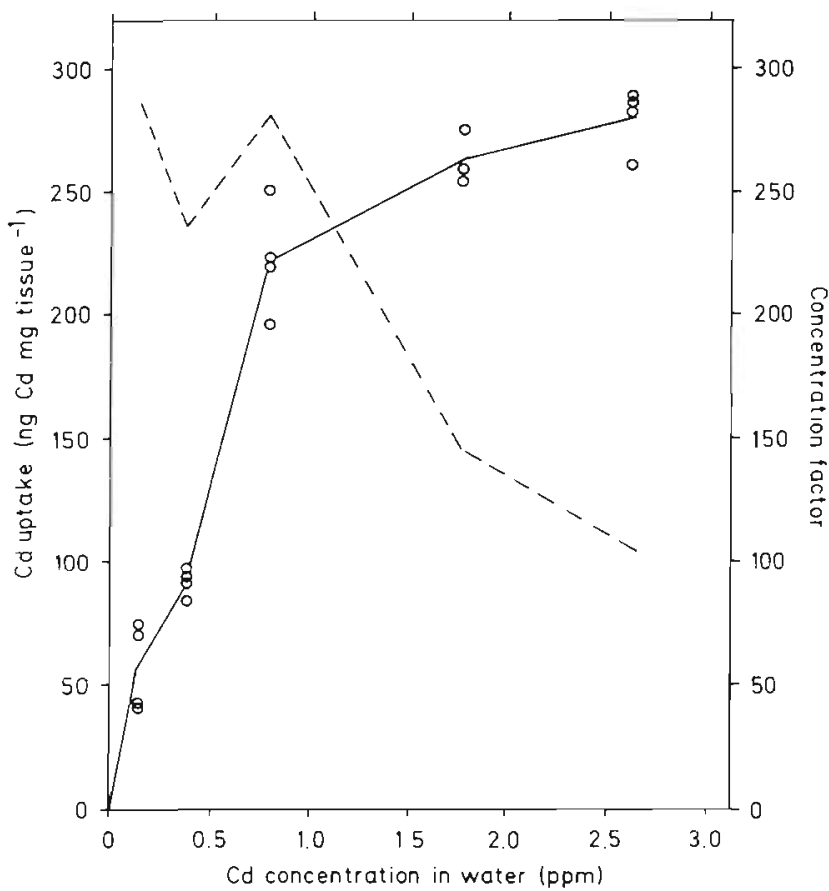

Fig. 4. Laminaria saccharina. Solid line: uptake of $\mathrm{Cd}$ in $6 \mathrm{~d}$ from various concentrations, expressed as ng $\mathrm{Cd}$ (mg dry weight tissue) ${ }^{-1}$; broken line: concentration factors (concentration in tissue/concentration in solution). Four plants measured per concentration approximately $2.3 \mathrm{ppm}$ Cd or more, the blades showed a sharply delimited distal loss of pigment (Fig. 2).

In experiments testing recovery of plants after $\mathrm{Cd}$ exposure, all plants grew after being returned to uncontaminated seawater, but there was no recovery from the reduced growth rates observed over the 6-d exposure period (Fig. 3). The growth per day over the whole $14 \mathrm{~d}$ (exposure plus subsequent culture in uncontaminated seawater) was poorer for all concentrations employed than that observed over $6 \mathrm{~d}$ of exposure to $\mathrm{Cd}$ (cf. Fig. 1). For plants which were $6 \mathrm{~d}$ in $\mathrm{Cd}$ and then $8 \mathrm{~d}$ in clean seawater, linear regression analysis ( $N=12$, including control plants) indicates a growth rate $50 \%$ of the control rate for plants exposed $6 \mathrm{~d}$ to a calculated concentration of $0.86 \mathrm{ppm} \mathrm{Cd}$. This is less than half the concentration producing this rate when growth is measured immediately after $6 \mathrm{~d}$ exposure. An increased time of exposure to a given concentration of $\mathrm{Cd}$ depresses growth more than does an increased concentration over a given time (Fig. 3). The control plants in the recovery experiments showed a mean increase $\mathrm{d}^{-1}$ of $21.16 \%$, when measured after 14 d. Plants exposed $1 \mathrm{~d}$ to $0.86 \mathrm{ppm} \mathrm{Cd}$ showed essentially no effect: $20.97 \%$ increase over the 14 -d period. However, plants exposed to $0.38 \mathrm{ppm} \mathrm{Cd}$ for $6 \mathrm{~d}$ increased over the 14 -d period only $15.27 \% \mathrm{~d}^{-1}$ and those exposed $6 \mathrm{~d}$ to $0.86 \mathrm{ppm} \mathrm{Cd}$ increased only $10.97 \% \mathrm{~d}^{-1}$ over the $14 \mathrm{~d}$, or approximately $50 \%$ of the control rate.

\section{Uptake of Cadmium}

Uptake of Cd corresponded roughly to the concentration available in the water, although the concentration factor (concentration in plants/concentration in water) was greater at lower ambient concentrations (Fig. 4). Measurements of the rate of uptake indicated that the plant is not at all saturated after $6 \mathrm{~d}$ in 0.75 ppm Cd, as the curve shows no signs of leveling out (Fig. 5). Uptake begins almost immediately and $9.5 \mathrm{ng}$ $\mathrm{Cd} \mathrm{mg} \mathrm{dry} \mathrm{weight}{ }^{-1}$ was detectable in the plant tissue after $1 \mathrm{~h}$ exposure to $0.75 \mathrm{ppm} \mathrm{Cd}$ (Fig. 5).

$\mathrm{Cd}$ is taken up most rapidly by the slowest-growing regions of the plant, i. e., the stipe and most distal portions of the blade, and least of all by the meristematic transition zone between the stipe and the blade (Fig. 6). Initially it seemed that the amount of uptake might be the same everywhere, with expansion of the growing region leading to a decline of Cd concentration $\mathrm{mg}^{-1}$ in the rapidly growing region by 'dilution' as suggested by Fuge and James (1973). This may play a small role in determining the relative concentrations. However, measurements of relative uptake after $1 \mathrm{~d}$ already showed essentially the same pattern as those 
after $6 \mathrm{~d}$, with only the total concentration in each region increasing with time (Fig. 6).

\section{Carbon Assimilation by Cd-Polluted Sporophytes}

Despite the rapid uptake of $\mathrm{Cd}$ from the culture medium, preliminary experiments showed that rates of carbon assimilation were little affected when 50-d-old plants were transferred from the Cd-free pretreatment medium into a radioactive incubation medium containing defined amounts of $\mathrm{Cd}$. However, when young sporophytes were grown for $24 \mathrm{~h}$ in a Cd-polluted medium and subsequently tested for potentials of carbon dioxide fixation, marked differences between $\mathrm{Cd}$ treated plants and unpolluted control plants were observed. The results are compiled in Table 1 . Since experiments on $\mathrm{Cd}$ uptake showed that different parts of the sporophytes accumulate different amounts of $\mathrm{Cd}$, various regions of the young Laminaria sporophytes were measured separately. The values of Table 1 demonstrate several facets of photosynthetic carbon assimilation in a Laminaria thallus. On a dry weight basis, rates of photosynthesis are highest in the distal part of the blade and somewhat lower in the region of the holdfast and stipe. The relatively lowest rates of photosynthesis are encountered in the intercalary growing zone of the young sporophyte. In all regions of

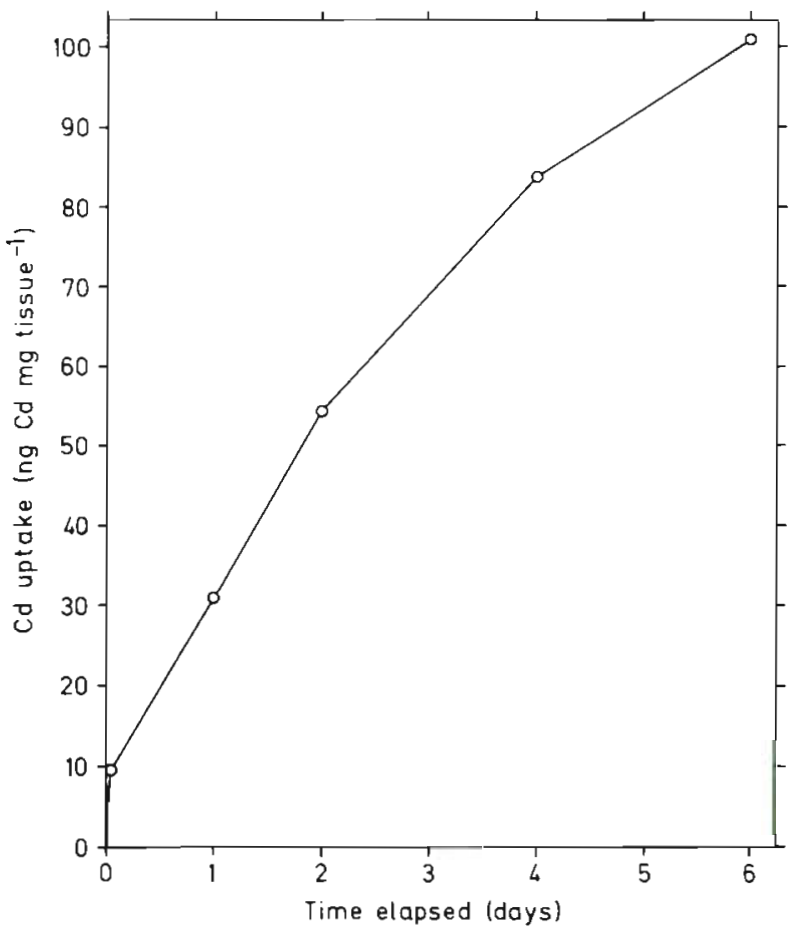

Fig. 5. Laminaria saccharina. Rate of uptake by whole plants exposed to $0.75 \mathrm{ppm} \mathrm{Cd}$. Concentration in tissue $=\mathrm{ng} \mathrm{Cd}$ (mg dry weight tissue) ${ }^{-1}$. One plant sampled at each time interval the thallus, rates of photosynthesis show concentration-dependent depressions. This Cd-dependent effect is relatively lower in the basal parts, whereas the distal region of the plant is more sensitive: in this region of the plant only $35 \%$ of the control rate is achieved after a 24 -h treatment in a medium containing $1.5 \mathrm{ppm} \mathrm{Cd}$. However, Cd toxicity is not only a concentration effect, but also implies time-dependent actions, as may be seen from a comparison of 24-h treated and 96-h treated specimens (Table 1).

Since various representatives of the Laminariales have been found to achieve appreciable rates of lightindependent carbon assimilation (cf. Kremer and Küppers, 1977), dark fixation in Cd-treated sporophytes

Table 1. Laminaria saccharina. Photosynthetic carbon assimilation - in nmol $\mathrm{CO}_{2}$ (100 $\mathrm{mg}$ dry weight $)^{-1} \mathrm{~h}^{-1}$ - by different parts of the plant, and effects of 24-h and 96-h treatment with various $\mathrm{Cd}$ concentrations

\begin{tabular}{|lccc|}
\cline { 3 - 4 } Condition & $\begin{array}{c}\text { Base } \\
\text { holdfast/stipe }\end{array}$ & $\begin{array}{c}\text { Blade } \\
\text { growing region }\end{array}$ & $\begin{array}{c}\text { Blade } \\
\text { distal part }\end{array}$ \\
\hline 24-h series & & & \\
Control & 1748 & 1654 & 2150 \\
$0.16 \mathrm{ppm} \mathrm{Cd}$ & 1559 & 1556 & 1978 \\
$0.28 \mathrm{ppm} \mathrm{Cd}$ & 1453 & 1428 & 1601 \\
$0.70 \mathrm{ppm} \mathrm{Cd}$ & 1385 & 1289 & 1445 \\
$1.07 \mathrm{ppm} \mathrm{Cd}$ & 1175 & 1188 & 1175 \\
$1.51 \mathrm{ppm} \mathrm{Cd}$ & 1258 & 1144 & 759 \\
96 -h series & & & \\
Control & 1598 & 1407 & 2288 \\
$0.16 \mathrm{ppm} \mathrm{Cd}$ & 1733 & 1368 & 1929 \\
$0.28 \mathrm{ppm} \mathrm{Cd}$ & 1450 & 1215 & 1446 \\
$0.70 \mathrm{ppm} \mathrm{Cd}$ & 1319 & 1112 & 998 \\
$1.07 \mathrm{ppm} \mathrm{Cd}$ & 1155 & 927 & 776 \\
$1.51 \mathrm{ppm} \mathrm{Cd}$ & 1082 & 828 & 523 \\
\hline
\end{tabular}

Table 2. Laminaria saccharina. Light-independent (dark) carbon fixation - in nmol $\mathrm{CO}_{2}(100 \mathrm{mg} \text { dry weight })^{-1} \mathrm{~h}^{-1}-$ by different parts of the plant, and effects of 24-h and 96-h treatment with various $\mathrm{Cd}$ concentrations

\begin{tabular}{|lccc|}
\hline \multicolumn{1}{|c}{ Condition } & $\begin{array}{c}\text { Base } \\
\text { holdfast/stipe }\end{array}$ & $\begin{array}{c}\text { Blade } \\
\text { growing region }\end{array}$ & $\begin{array}{c}\text { Blade } \\
\text { distal part }\end{array}$ \\
\hline 24-h series & & & \\
Control & 165 & 346 & 258 \\
0.16 ppm Cd & 161 & 222 & 211 \\
0.28 ppm Cd & 126 & 167 & 231 \\
0.70 ppm Cd & 97 & 76 & 176 \\
1.07 ppm Cd & 95 & 114 & 141 \\
1.51 ppm Cd & 69 & 93 & 148 \\
$96-$ h series & & & \\
Control & 186 & 313 & 202 \\
0.16 ppm Cd & 157 & 217 & 189 \\
0.28 ppm Cd & 134 & 103 & 184 \\
$0.70 \mathrm{ppm} \mathrm{Cd}$ & 110 & 98 & 166 \\
$1.07 \mathrm{ppm} \mathrm{Cd}$ & 76 & 90 & 129 \\
$1.51 \mathrm{ppm} \mathrm{Cd}$ & 59 & 76 & 72 \\
\hline
\end{tabular}


was also tested. The results are shown in Table 2. Control specimens showed the highest rates of dark carbon fixation in the growing zone (proximal part of the blade). In contrast to the results of photosynthetic carbon assimilation, this zone in particular is rather sensitive to $\mathrm{Cd}$. The inhibition of dark fixation by $\mathrm{Cd}$, seen also to a lesser extent in the distal part of the blade and in the holdfast region, proved to be time and concentration dependent as well (Table 2).

\section{Pigment Content}

Young sporophytes of Laminaria showed notable loss of pigment, particularly in the distal part of the blade, after some days incubation in sublethal $\mathrm{Cd}$ concentrations. Table 3 gives a quantification of this effect for various regions of young plants, which were also tested for their carbon assimilation potentials. It is obvious that differential sensitivity to $\mathrm{Cd}$ is exhibited by different thallus regions. Holdfasts and stipes seem to be rather unaffected even by $\mathrm{Cd}$ concentrations over $1.5 \mathrm{ppm}$ and like the growing region (proximal half of the blade) are bleached only by relatively high $\mathrm{Cd}$ concentrations. The distal part of the young blade, on the other hand, is the most sensitive region of the sporophyte, losing over $90 \%$ of its total pigment (chlorophyll $a$ and fucoxanthin) at concentrations over 1.5 ppm Cd after $6 \mathrm{~d}$.

\section{DISCUSSION AND CONCLUSIONS}

The concentrations of $\mathrm{Cd}$ tested in these experiments are all considerably higher than those found in the North Sea or in open-ocean waters. However, all these

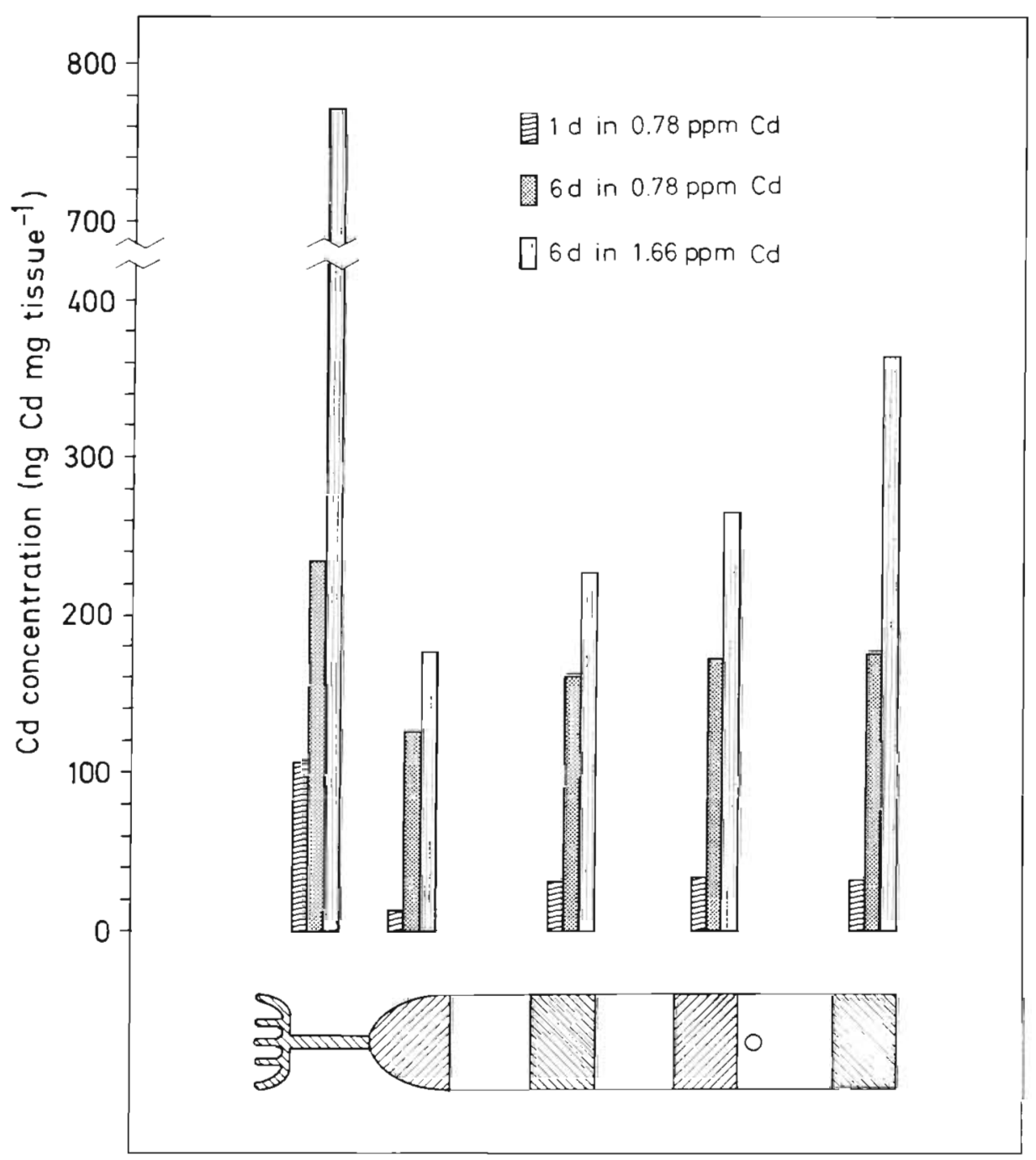

Fig. 6. Laminaria saccharina. Concentration of $\mathrm{Cd}$, expressed as $\mathrm{ng} \mathrm{Cd}\left(\mathrm{mg} \mathrm{dry}\right.$ weight tissue) ${ }^{-1}$ in different regions of a plant after $1 \mathrm{~d}$ and $6 \mathrm{~d}$ 
Table 3. Laminaria saccharina. Pigment (chlorophyll a and fucoxanthin) content of sporophytes treated for $6 \mathrm{~d}$ with various Cd concentrations. Values expressed as $\mu \mathrm{g}$ pigment $/ 100 \mathrm{mg}$ dry weight. Average values of three replicates

\begin{tabular}{|c|c|c|c|c|c|c|}
\hline \multirow[t]{2}{*}{ Conditions } & \multicolumn{2}{|c|}{$\begin{array}{c}\text { Base } \\
\text { holdfast/stipe }\end{array}$} & \multicolumn{2}{|c|}{$\begin{array}{c}\text { Blade } \\
\text { growing zone }\end{array}$} & \multicolumn{2}{|c|}{$\begin{array}{c}\text { Blade } \\
\text { distal part }\end{array}$} \\
\hline & chl $a$ & fucox. & chl a & fucox. & chl $a$ & fucox. \\
\hline Control & 80.1 & 26.9 & 139.6 & 32.6 & 203.8 & 65.4 \\
\hline $0.23 \mathrm{ppm} \mathrm{Cd}$ & 81.9 & 27.6 & 142.2 & 38.9 & 182.6 & 59.1 \\
\hline $0.46 \mathrm{ppm} \mathrm{Cd}$ & 79.0 & 26.2 & 144.2 & 39.5 & 196.2 & 63.6 \\
\hline $0.80 \mathrm{ppm} \mathrm{Cd}$ & 85.7 & 31.2 & 177.8 & 48.7 & 152.3 & 49.4 \\
\hline $1.05 \mathrm{ppm} \mathrm{Cd}$ & 82.4 & 27.1 & 128.3 & 35.0 & 103.1 & 33.4 \\
\hline $1.66 \mathrm{ppm} \mathrm{Cd}$ & 87.4 & 29.5 & 80.6 & 21.9 & 17.7 & 5.5 \\
\hline
\end{tabular}

experiments were short-term experiments and designed to give an indication of the sublethal effects of Cd within a workable time span. As the plants were growing rapidly during the experiments, the results give a good indication of the effects of $\mathrm{Cd}$. The rate of growth also necessarily limited the time which the experiments could be run under these conditions. Results of thinning in cultures where plants were grown to test size for the experiments reported here show that crowding of culture vessels inhibits growth greatly. These experiments indicate that this is true also when the plants are subjected to $\mathrm{Cd}$ pollution. Thus where plants were removed over the course of the experiment, growth of the remaining plants was greater than in the same Cd concentration when more plants were present. Previous studies and these experiments have shown that slower-growing plant parts take up more $\mathrm{Cd}$. These experiments indicate that slowergrowing plants as a whole also take up more $\mathrm{Cd}$.

Experiments in which plants were exposed for various periods to $\mathrm{Cd}$ and then removed to grow further in clean water indicate two important points with regard to time. First, long-term after effects are far more serious than is apparent from measurements taken immediately after $\mathrm{Cd}$ exposure. Thus, after $14 \mathrm{~d}$, the concentration producing a reduction in growth to $50 \%$ of the control was less than half that required for the same effect in $6 \mathrm{~d}$, although in both cases exposure to $\mathrm{Cd}$ lasted only $6 \mathrm{~d}$. Secondly, time of exposure to $\mathrm{Cd}$ was more important in reducing growth than was the concentration to which the plants were exposed. Thus, a 1-d exposure to $\mathrm{Cd}$ at any concentration had not produced a significant reduction in growth when the plants were measured 2 weeks later, whereas plants exposed $6 \mathrm{~d}$ showed significant growth reductions at all concentrations tested. These results indicate that chronic low-level Cd pollution may be as serious in the long run as the higher concentrations employed here. It is probable that the lethal dose is far below $4.5 \mathrm{ppm}$, if it is applied over a longer time.
One visible symptom of $\mathrm{Cd}$ toxicity below $2.0 \mathrm{ppm}$ was a decrease in growth, which corresponds to results reported for a variety of terrestrial plants (Haghiri, 1973; Turner, 1973; Lamoreaux and Chaney, 1977). Another symptom of $\mathrm{Cd}$ effects is a significant dose and time-dependent reduction of both photosynthetic as well as light-independent carbon assimilation rates with different sensitivity in different regions of the test plants (Tables 1 and 2). Inhibitory effects on algal photosynthesis by several heavy metals including $\mathrm{Cd}$ were earlier reported by Overnell (1976) for a variety of unicellular marine algae.

A third symptom, the distal loss of pigment, which occurs particularly at higher concentrations, is a curious feature. Pybus (1973) reported a similar effect of detergent on Laminaria, but did not mention a sharp boundary to the unpigmented zone, as observed here. It was reported that soybeans show chlorosis of the younger leaves at higher $\mathrm{Cd}$ concentrations (Haghiri, 1973), but in contrast, the distal portions of the Laminaria blades which show chlorosis are older rather than younger. In lethal concentrations, the pigment loss extended down into the meristematic zone, leaving only the stipe still pigmented. We have shown, however, that the stipe accumulates the greatest amount of Cd. The pigment loss is thus not correlated with accumulated Cd content. A comparison of Tables 1 and 3 shows that assimilation-rate depressions are also not well correlated with pigment decay. This may indicate that a decrease in the photosynthetic potential (Table 1) of Cd-polluted plants is not caused primarily by pigment loss, but is probably due to other effects. The same is true for dark carbon assimilation, since the enzyme responsible for light-independent carboxylation, phosphoenolpyruvate carboxykinase, is located outside the chloroplasts.

The results here agree with previous reports that the uptake of $\mathrm{Cd}$ is not regulated and leads to high concentration factors. These short-term experiments did not give an indication of the time to reach equilibrium. 
Bryan (1969), working with pieces of Laminaria exposed to $\mathrm{Zn}$, reported that after $30 \mathrm{~d}$ plant pieces were still not in equilibrium with their environment. $\mathrm{As} \mathrm{Cd}$ is chemically related to $\mathrm{Zn}$ in many ways, the time required for uptake may be similar. As equilibrium was not reached, no figures can be given at this time for the potential concentration of $\mathrm{Cd}$ which could be accumulated by Laminaria, but it is obviously high.

These experiments suggest that the use of fieldcollected plants of Laminaria saccharina as indicators of environmental $\mathrm{Cd}$ pollution could be a promising method. The concentration of $\mathrm{Cd}$ in the Laminaria tissues is higher where the environmental concentrations are higher and the plants integrate $\mathrm{Cd}$ over an entire period of exposure because uptake begins almost immediately. As the concentration factors are high, even small amounts of environmental $\mathrm{Cd}$ can be detected. On the basis of available data, there is no evidence that $\mathrm{Cd}$ was lost from plants after they were returned to clean water, but this should be tested further. If there is indeed no loss, this would agree with other authors and is another point in favor of Laminaria plants as possible pollution indicators. Caution should be exercised, however, in interpreting the results quantitatively, as there are several potential sources of error. Although no $\mathrm{Cd}$ may be lost from living plants, above a certain size, Laminaria plants slough off distal tissue as they grow. As the distal tissues were shown to contain the second highest concentrations of $\mathrm{Cd}$ after the stipe, this loss of tissue could seriously affect estimates of total Cd taken up. As shown in this study and pointed out earlier by Bryan (1969), uptake to equilibrium is slow and thus rapid environmental fluctuations would not be indicated. Fuge and James (1974) as well as Morris and Bale (1975) have reviewed several sources of error in using brown algae as indicators. There are marked seasonal changes in concentration within the same species, as would be expected, since this study has shown that the rate and amount of uptake depends on growth rate. Fuge and James (1974) further noted that older plant tissues contain higher concentrations, as has been shown in this study as well. Considering all these factors, and in agreement with Bryan and Hummerstone (1973), Laminaria plants should be useful as indicators of changes, if entire plants of the same age, or the same portions of such plants, are collected for analyses on the same site in the same season in subsequent years. A test of this method, taking into account the data in this study, remains to be carried out.

Acknowledgements. The authors wish to thank Dr. K. Lüning, Biologische Anstalt Helgoland, for valuable discussions. They acknowledge the support of a Project Grant from the Federal Ministry for Research and Technology (Bonn) to J. W. M. and K. R. S.

\section{LITERATURE CITED}

Bryan, G. W. (1969). The absorption of zinc and other metals by the brown seaweed Laminaira digitata. J. mar. biol. Ass. U. K. 49: 225-243

Bryan, G. W., (1971). The effects of heavy metals (other than mercury) on marine and estuarine organisms. Proc. R. Soc. (B) 177: 398-410

Bryan, G. W., Hummerstone, L. G. (1973). Brown seaweed as an indicator of heavy metals in estuaries of south-west England. J. mar. biol. Ass. U. K. 53; 705-720

Burrows, E. M. (1971). Assessment of pollution effects by the use of algae. Proc. R. Soc. (B) 177: 295-306

Burrows, E. M., Pybus, C. (1971). Laminaria saccharina and marine pollution in northeast England. Mar. Pollut. Bull. 2: $53-56$

Friberg, L., Piscador, M., Nordberg, G. F., Kjellström, T (eds) (1974). Cadmium in the environment, CRC Press, Cleveland

Fuge, R., James, K. H. (1973). Trace metal concentrations in brown seaweeds, Cardigan Bay, Wales. Mar. Chem. 1: 281-293

Fuge, R., James, K. H. (1974). Trace metal concentrations in Fucus from the Bristol Channel. Mar. Pollut. Bull. 5: 9-12

Goldberg, E. D. (1965). Minor elements in seawater. In: Riley, G. P., Skirrow, G. (eds) Chemical oceanography, Vol. 1. Academic Press, London, pp. 163-196

Haghiri, F. (1973). Cadmium uptake by plants. J. envir. Qual. 2: $93-96$

Hopkin, R., Kain, J. M. (1971). The effect of marine pollutants on Laminaria hyperborea. Mar. Pollut. Bull. 2: 75-77

Hopkin, R., Kain, J. M. (1978). The effects of some pollutants on the survival, growth and respiration of Laminaria hyperborea. Estuar \& coast. mar. Sci. 7: 531-553

Kobayashi, J. (1970). Relations between the 'itai itai disease' and the pollution of river water by cadmium from a mine. Proc. Int. Water Pollut. Res. Conf. 1970: 1-25

Kremer, B. P. (1978). Determination of photosynthetic rates and ${ }^{14} \mathrm{C}$ photoassimilatory products of brown seaweeds. In: Hellebust, J. A., Craigie, J. S. (eds) Handbook of phycological methods. University Press, Cambridge, pp. 269-283

Kremer, B. P., Küppers, U. (1977). Carboxylating enzymes and pathway of photosynthetic carbon assimilation in different marine algae - evidence for the $\mathrm{C}_{4}$-pathway? Planta 113 $191-196$

Lamoreaux, R. J., Chaney, W. R. (1977). Growth and water movement in silver maple seedlings affected by cadmium. J. envir. Qual. 6: 201-205

Markham, J. W., Lüning, K., Sperling, K. R. (1979). Automatic culture systems for growing Laminaria saccharina (Phaeophyta) and testing the effects of pollutants. Proc. Int. Seaweed Symp. 9: 153-159

Morris, A. W., Bale, A. J. (1975). The accumulation of cadmium, copper, manganese and zinc by Fucus vesiculosus in the Bristol Channel. Estuar. \& coast. mar. Sci. 3: 153-163

Overnell, J. (1976). Inhibition of marine algal photosynthesis by heavy metals. Mar Biol. 38: 335-342

Preston, A. (1973). Heavy metals in British waters. Nature, Lond 242: 95-97

Provasoli, L. (1968). Media and prospects for culture of marine algae. In: Watanabe, A., Hattori, A. (eds) Cultures and collections of marine algae. Jap. Soc. Physiol., Tokyo, pp. 63-75

Pybus, C. (1973). Effects of anionic detergent on the growth of Laminaria. Mar. Pollut. Bull. 4: 74-76 
Riley, J. P., Taylor, D. (1968). Chelating resins for the concentration of trace elements from seawater and their use in conjunction with atomic absorption spectrophotometry. Analytica chim. Acta 40: 479-485

Seeliger, U., Edwards, P. (1977). Correlation coefficients and concentration factors of copper and lead in seawater and benthic algae. Mar. Pollut. Buil. 8: 16-18

Schmidt, E. (1976). Distribution of seven trace metals in the seawater of the inner German Bight. Coun. Meet. int. Coun. Explor. Sea (C.M. - I.C.E.S.) C 10

Sperling, K. R. (1977). Determination of heavy metals in seawater and marine organisms by flameless atomic absorption spectrophotometry. VI. Cadmium determination in culture waters from toxicological experiments with marine organisms. Z. analyt. Chem. 287: 23-27

Sperling, K. R., Bahr, B., Kremling, K. (1977). Heavy metal determination in seawater and marine organisms with the aid of flameless AAS. IV Description of a routine method for the determination of cadmium in small samples of biological material. Z. Lebensmittelunters. -Forsch. 163: $87-91$

Turner, M. A. (1973). Effect of cadmium treatment on cadmium and zinc uptake by selected vegetable species. J. envir. Qual. 2: 118-119

This paper was presented by Dr. H. Rosenthal; it was accepted for printing on March 7, 1980 